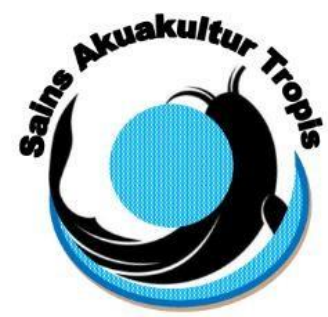

\author{
Jurnal Sains Akuakultur Tropis \\ De parte me n A $k$ a $k$ u I t u r \\ Fakultas Perikanan dan IImu Kelautan - Universitas Diponegoro \\ JI. Prof. Soedarto, SH, Tembalang, Semarang 50275 \\ Telp. (024) 7474698, Fax.: (024) 7474698
}

Email: sainsakuakulturtropis@gmail.com, sainsakuakulturtropis@undip.ac.id

\title{
PENAMBAHAN EKSTRAK Sargassum sp. HASIL EKSTRAKSI ENZIMATIK PADA PAKAN TERHADAP PERFORMA PERTUMBUHAN UDANG VANAME (Litopenaeus vannamei)
}

\author{
Addition of Sargassum sp. from Enzimatic Extraction on Feed to the Growth Performance of White Shrimp \\ (Litopenaeus vannamei)
}

Tri Mulyadi, Sarjito*, Diana Rachmawati

Departemen Akuakultur,

Fakultas Perikanan dan Ilmu Kelautan, Universitas Diponegoro

Jl. Prof. Soedarto, SH, Tembalang, Semarang, Jawa Tengah - 50275, Telp/Fax, +6224 7474698

*Corresponding author: sarjito_msdp@yahoo.com

\begin{abstract}
ABSTRAK
Intensifikasi budidaya udang vaname (L. vannamei) menyebabkan akumulasi limbah budidaya di perariran dan stres lingkungan yang menjadi penyebab organisme patogen berkembang serta menyerang organisme budidaya, sehingga terjadi kematian massal. Upaya yang dapat dilakukan untuk mengatasi hal tersebut melalui produksi pakan dengan menambahkan bahan yang dapat meningkatkan sistem imun tubuh, namun juga berfungsi sebagai growth promoter. Bahan yang memiliki kedua fungsi tersebut adalah rumput laut Sargassum sp. Tujuan penelitian ini, mengetahui pengaruh penambahan ekstrak sargassum hasil ekstraksi enzimatik pada pakan terhadap performa pertumbuhan laju pertumbuhan spesifik/SGR dan rasio konversi pakan/FCR udang vaname $(L$. vannamei). Penelitian dilakukan dengan metode eksperimental menggunakan rancangan acak lengkap (RAL) dengan 3 perlakuan dan 2 kali pengulangan. Perlakuan yang dilakukan, yaitu A (pakan dengan penambahan ekstrak sargassum $0 \mathrm{~g} / \mathrm{kg}$ pakan), B (pakan dengan penambahan ekstrak sargassum enzimatik protease $2 \mathrm{~g} / \mathrm{kg}$ pakan) dan $\mathrm{C}$ (pakan dengan penambahan ekstrak sargassum enzimatik karbohidrase $2 \mathrm{~g} / \mathrm{kg}$ pakan). Hasil penelitian menunjukan, pakan dengan penambahan ekstrak sargassum hasil ekstraksi enzimatik berpengaruh nyata $(\mathrm{P}<0,05)$ terhadap laju pertumbuhan spesifik (SGR) dan rasio konversi pakan (FCR). Kualitas air media pemeliharaan berada dalam kisaran yang layak untuk budidaya udang.
\end{abstract}

Kata Kunci : Sargassum sp.; L. vannamei; Ekstrak Enzimatik; Pertumbuhan

\section{ABSTRACT}

Intensification of white shrimp (L. vannamei) cultivation causes accumulation of waste aquaculture in the water and environmental stress which causes pathogenic organisms to develop and attack aquaculture organisms, so that mass deaths occur. Various efforts have been made to overcome this through feed production by adding ingredient that can enhance the body's immune system, but also function as growth promoters. The material that has both functions is seaweed Sargassum sp. The aims of this study was to determine the addition effect of sargassum extract from enzymatic extraction on feed to the specific growth rate/SGR and feed convertion ratio/FCR of white shrimp (L. vannamei). These study was conducted by experimental method used a completely randomized design (CRD) with 3 treatments and 2 repetitions. The treatment was namely $A$ (feed with the addition of sargassum extract $0 \mathrm{~g} / \mathrm{kg}$ feed), B (feed with the addition of enzymatically protease sargassum extract $2 \mathrm{~g} / \mathrm{kg}$ feed) and $C$ (feed with the addition of enzymatically carbohydrase sargassum extract $2 \mathrm{~g} / \mathrm{kg}$ feed). The results showed that the feed with the addition of sargassum extract from enzymatic extraction had a significant effect $(P<0,05)$ on specific growth rate $(S G R)$ and feed conversion ratio $(F C R)$. Water quality of media is in the proper range for shrimp farming.

Keywords: Sargassum sp.; L. vannamei; Enzymatic Extract; Growth 


\section{PENDAHULUAN}

Kementerian Kelautan dan Perikanan Indonesia (2018) menyatakan bahwa udang masih menjadi komoditas unggulan dalam perikanan setelah rumput laut. Volume produksi udang terus mengalami peningkatan 607.152 ton (2015), 692.568 ton (2016) dan 919.987 ton (2017). Sedangkan Rohmin et al. (2017) mengungkapkan, selain permintaan di pasar dunia cukup besar, udang vaname memiliki pertumbuhan yang relatif cepat, serta memiliki keistimewaan karena mampu dibudidayakan dengan padat penebaran yang tinggi (intensif).

Peningkatan produksi melalui intensifikasi budidaya menyebabkan akumulasi limbah budidaya di perairan sehingga dapat menjadi masalah baru yaitu menyebabkan stres lingkungan dan menjadi faktor berkembangnya organisme patogen. Rohmin et al. (2017) mengungkapkan bahwa organisme patogen yang menghambat produksi budidaya udang diantaranya bakteri, virus, jamur dan parasiter. Organisme patogen, khususnya virus (Sudaryono et al., 2018b) dan bakteri (Sivagnanavelmurugan et al., 2012), yang menyerang budidaya udang dengan mudah menyebabkan kematian massal pada udang.

Upaya-upaya yang dilakukan dalam menangani kematian massal pada udang saat ini, belum ditemukan suatu cara yang optimal. Salah satu upaya yang dapat dilakukan sebagai tindakan preventif adalah pemberian pakan dengan penambahan bahan alam yang dapat meningkatkan sistem imun tubuh dan meningkatkan pertumbuhan, yakni rumput laut. Ketersediaan rumput laut di alam maupun produksi budidayanya yang melimpah menjadi kelebihan yang melekat padanya. Beberapa penelitian pada rumput laut, diketahui dapat meningkatkan sistem imun udang sehingga memengaruhi kelangsungan hidup organisme budidaya (Sivagnanavelmurugan et al., 2012; Sudaryono et al., 2018b; Schleder et al., 2017a).

Penelitian yang dilakukan tidak terbatas pada salah satu spesies rumput laut saja, namun juga pada spesies yang lain diantaranya Dictyota sp., Gracilaria sp., Padina sp., Sargassum sp., Halimeda sp., G. pistillata, Gigartina aciculaire, E. cottoni, E. spinosa, S. polycystum, dan S. microcystum (Ridlo dan Pramesti, 2009; Subagiyo, 2008; Yeh dan Chen, 2008; Arizo et al., 2015; Giang et al., 2016). Penelitian penggunaan rumput laut sebagai growth promoter dilakukan melalui berbagai metode, diantaranya ekstraksi air panas (Sudaryono et al., 2015a) dan dalam bentuk tepung (Sahara 2017).

Beberapa tahun terakhir telah ditemukan metode ekstraksi baru, yaitu metode ekstraksi enzimatik sebagai alternatif baru untuk mengoptimalkan hasil/produk ekstraksi (Denis et al., 2009; Wijesinghe et al., 2012; Boulila et al., 2015; Charoensiddhi et al., 2016). Namun, penelitian rumput laut yang dihasilkan melalui proses ekstraksi enzimatik sebagai growth promoter pada organisme budidaya belum pernah dilakukan. Oleh sebab itu, perlu dilakukan penelitian tersebut. Tujuan penelitian ini adalah mengetahui pengaruh penambahan ekstrak sargassum hasil ekstraksi enzimatik pada pakan terhadap performa pertumbuhan (SGR dan FCR) udang vaname ( $L$. Vannamei).

\section{MATERI DAN METODE}

Penelitian ini dilakukan pada bulan Mei-Juli 2018 bertempat di Laboratorium Manajemen Kesehatan Hewan Akuatik Balai Besar Perikanan Budidaya Air Payau (BBPBAP) Jepara. Prosedur penelitian yang dilakukan terdiri dari persiapan media air, wadah, pakan, dan pemeliharaan hewan uji.

Bahan ekstrak sargassum diperoleh dengan cara ekstraksi melalui metode Puspita et al. (2017). Hewan yang digunakan dalam penelitian ini adalah 300 ekor udang vaname (L. vannamei) dengan ukuran bobot rata-rata 10,63 $\pm 0,3 \mathrm{~g}$ /ekor. Udang didapatkan dari tambak pembesaran BBPBAP Jepara. Wadah penelitian yang digunakan berupa plastic tank dengan ukuran 0,687 (p) x 0,390 (l) x 0,476 (t) m sebanyak 6 unit. Wadah diisi dengan volume air 60 L yang dilengkapi sistem aerasi. Padat tebar udang vaname (L. Vannamei) yang digunakan dalam penelitian sebanyak 1 ekor/4 L.

Udang diadaptasi selama 2 minggu dan dipuasakan 1 hari sebelum dilakukan perlakuan. Udang vaname dipelihara selama 28 hari dan diberi pakan pellet sebesar $5 \%$ dari bobot biomass. Pakan buatan yang diberikan berupa pelet komersil produksi PT. STP (Suri Tani Pemuka) kode 683 SP. Penambahan bahan ekstrak sargassum hasil ekstraksi enzimatik ke dalam pakan dilakukan menggunakan metode coating dengan cara disprayer. Frekuensi pemberian pakan dilakukan sebanyak 4 kali sehari. Waktu pemberian pakan diadaptasi dari Yudiati et al. (2016), pukul 06:00, 11:00, 16:00, dan 21:00. Pergantian air 30\% dilakukan setiap hari dengan cara disifon.

Penelitian dilakukan dengan metode eksperimental. Rancangan percobaan yang digunakan adalah rancangan acak lengkap (RAL) yang terdiri dari 3 perlakuan dan 2 kali pengulangan. Perlakuan tersebut yaitu perlakuan A (pakan dengan penambahan ekstrak sargassum $0 \mathrm{~g} / \mathrm{kg}$ pakan), B (pakan dengan penambahan ekstrak sargassum enzimatik protease $2 \mathrm{~g} / \mathrm{kg}$ pakan) dan $\mathrm{C}$ (pakan dengan penambahan ekstrak sargassum enzimatik karbohidrase $2 \mathrm{~g} / \mathrm{kg}$ pakan). 


\section{Laju pertumbuhan spesifik (SGR)}

Menurut Hepher (1988), perhitungan laju pertumbuhan spesifik dilakukan dengan menggunakan rumus sebagai berikut:

$$
\mathrm{G}_{\mathrm{w}}=\frac{\ln \mathrm{W}_{\mathrm{t}}-\ln \mathrm{W}_{0}}{\mathrm{t}-\mathrm{t}_{0}} \times 100
$$

Keterangan :

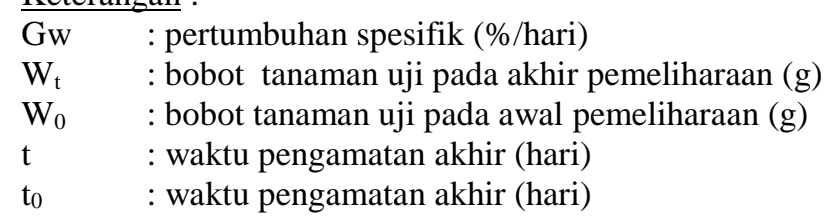

\section{Rasio konversi pakan (FCR)}

Menurut Tacon (1987), perhitungan rasio konversi pakan dilakukan dengan menggunakan rumus:

Keterangan:

$$
\mathrm{FCR}=\frac{\mathrm{F}}{\left(\mathrm{W}_{\mathrm{t}}+\mathrm{D}\right)-\mathrm{W}_{0}}
$$

FCR : rasio konversi pakan

$\mathrm{F} \quad$ : jumlah pakan yang dikonsumsi (g)

$\mathrm{W}_{\mathrm{t}} \quad$ : bobot total ikan pada akhir pemeliharaan $(\mathrm{g})$

D : bobot total ikan yang mati $(\mathrm{g})$

$\mathrm{W}_{0} \quad$ : bobot total ikan pada awal pemeliharaan $(\mathrm{g})$

\section{Kualitas Air}

Variabel kualitas air yang diamati selama penelitian adalah DO $(\mathrm{mg} / \mathrm{L})$ dan suhu $\left({ }^{\circ} \mathrm{C}\right)$ menggunakan water quality checker merek YSI Pro20, derajat keasaman $(\mathrm{pH})$ menggunakan $\mathrm{pH}$ meter dan salinitas (ppt) menggunakan handrefraktometer.

\section{Analisis Data}

Analisis data performa pertumbuhan, SGR dan FCR, dilakukan dengan metode analisis one way anova $(\alpha=0,05)$ melalui program Ms. Excel. Data tersebut dianalisis setelah dilakukan uji statistika pendahuluan yaitu uji normalitas, uji homogenitas, dan uji additivitas. Perlakuan yang berpengaruh nyata $(\mathrm{P}<0,05)$ kemudian dilakukan uji post hoc test Duncan $(\mathrm{P}<0,05)$. Data kualitas air sebagai data pendukung.

\section{HASIL}

\section{Performa Pertumbuhan}

Penambahan ekstrak sargassum hasil ekstraksi enzimatik berpengaruh nyata $(\mathrm{P}<0,05)$ terhadap performa pertumbuhan udang vaname (L. vannamei), SGR maupun FCR. SGR tertinggi terjadi pada perlakuan penambahan ekstrak sargassum enzimatik karbohidrase (C) dengan nilai 1,38 $\pm 0,03 \%$ /hari, kemudian ekstrak sargassum enzimatik protease (B) sebesar 1,36 $\pm 0,06 \%$ hari, dan terendah pada perlakuan tanpa penambahan ekstrak

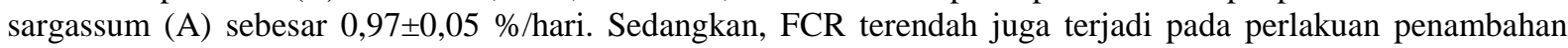
ekstrak sargassum enzimatik karbohidrase (C) dengan nilai 1,94 $\pm 0,04$, kemudian ekstrak sargassum enzimatik protease (B) 1,96 $\pm 0,01$ dan tertinggi pada perlakuan tanpa penambahan ekstrak sargassum (A) sebesar 2,50 $\pm 0,18$. Hasil pengamatan performa pertumbuhan udang vaname (L. vannamei) dapat dilihat pada Tabel 1.

Tabel 1. Performa Pertumbuhan Udang Vaname (L. vannamei)

\begin{tabular}{lccc}
\hline \multirow{2}{*}{ Parameter } & \multicolumn{3}{c}{ Perlakuan $(\mathrm{g} / \mathrm{kg}$ pakan $)$} \\
\cline { 2 - 4 } & $\mathrm{A}$ & $\mathrm{B}$ & $\mathrm{C}$ \\
\hline SGR (\%/hari) & $0,97 \pm 0,05^{\mathrm{b}}$ & $1,36 \pm 0,06^{\mathrm{a}}$ & $1,38 \pm 0,03^{\mathrm{a}}$ \\
FCR & $2,50 \pm 0,18^{\mathrm{b}}$ & $1,96 \pm 0,01^{\mathrm{a}}$ & $1,94 \pm 0,04^{\mathrm{a}}$ \\
\hline
\end{tabular}

Keterangan: huruf superscript yang sama menunjukkan tidak terdapat perbedaan yang nyata $(\mathrm{P}>0,05)$

\section{Kualitas Air Media}


Hasil pengukuran kualitas air pada media pemeliharaan selama penelitian masih dalam kondisi yang layak untuk kehidupan udang vaname (L. vannamei). Kualitas air media pemeliharaan udang vaname dapat dilihat pada Tabel 2.

Tabel 2. Parameter Kualitas Air Media Pemeliharaan Udang Vaname

\begin{tabular}{|c|c|c|c|c|}
\hline \multirow{2}{*}{ Parameter } & \multicolumn{3}{|c|}{ Perlakuan } & \multirow{2}{*}{ kelayakan } \\
\hline & $\mathrm{A}$ & $\mathrm{B}$ & $\mathrm{C}$ & \\
\hline DO (mg/L) & $3,01-4,16$ & $3,00-4,36$ & $3,00-4,23$ & $>3^{a}$ \\
\hline Suhu $\left({ }^{\circ} \mathrm{C}\right)$ & $26,40-28,90$ & $26,40-28,90$ & $26,50-28,90$ & $25-30^{\mathrm{b}}$ \\
\hline Salinitas (ppt) & $26-30$ & $26-30$ & $25-30$ & $1-40^{\mathrm{b}}$ \\
\hline $\mathrm{pH}$ & $7,20-8,20$ & $7,20-8,00$ & $7,10-8,00$ & $6-9^{a}$ \\
\hline
\end{tabular}

Keterangan: ${ }^{\mathrm{a}}$ Ferreira et al. $(2011),{ }^{\mathrm{b}}$ Mohanty et al. (2018)

\section{PEMBAHASAN}

Penambahan ekstrak sargassum hasil ekstraksi enzimatik pada pakan memiliki pengaruh yang nyata (P $<0,05)$ terhadap SGR udang vaname (L. vannamei). Hasil penelitian ini menunjukkan bahwa penambahan ekstrak sargassum mampu meningkatkan laju pertumbuhan spesifik pada udang vaneme (L. vannamei). Penelitian sebelumnya yang dilakukan oleh Yu et al. (2016) melaporkan bahwa laju pertumbuhan spesifik (SGR) udang vaname secara signifikan terjadi pada udang yang diberi pakan dengan kandungan $20 \mathrm{dan} 30 \mathrm{~g} / \mathrm{kg}$ G. lemaneiformis setelah pemeliharaan 8 minggu. Meskipun pada setiap perlakuan mengalami pertumbuhan, namun udang yang diberi pakan dengan penambahan $2 \mathrm{~g} / \mathrm{kg}$ ekstrak sargassum enzimatik karbohidrase menunjukkan yang tertinggi. Pertumbuhan tersebut terjadi diduga berasal dari aktivitas penyerapan nutrisi pakan oleh udang, hal itu ditunjukkan oleh rendahnya nilai FCR (table 1) pada perlakuan penambahan ekstrak sargassum hasil ekstraksi enzimatik.

Aktivitas penyerapan nutrisi tersebut diduga dipengaruhi oleh kandungan bahan aktif yang terdapat didalam ekstrak sargassum, sehingga terjadi peningkatan kinerja aktivitas enzim pencernaan pada udang vaname ( $L$. vannamei). Azad et al. (2005) mengemukakan peningkatan pertumbuhan oleh polisakrida dimungkinkan oleh daya cerna nutrisi yang lebih baik melalui peningkatan aktivitas enzim pencernaan. Schleder et al. (2018b), menegaskan dalam penelitiannya bahwa terjadi peningkatan aktivitas absolut enzim amilase dan lipase pada hepatopankreas udang vaname (L. vannamei) yang diberi pakan mengandung 0,5, 2 dan $4 \%$ S. filipendula sehingga menghasilkan biomassa akhir yang tinggi dibandingkan dengan kontrol, masing-masing 12,99, 12,86 dan 13,26 g. Hasil penelitian yang dilakukan oleh Puspita et al. (2017) diketahui bahan aktif yang terdapat dalam ekstrak sargassum hasil ekstraksi enzimatik berasal dari senyawa fenol, yaitu florotannin. Diduga kuat bahwa kandungan senyawa aktif tersebut memengaruhi aktivitas enzim pencernaan. Mekanisme yang spesifik bagaimana proses bahan aktif, dalam hal ini senyawa fenol-florotannin, dari ekstrak sargassum pada pakan memengaruhi pertumbuhan memang belum diteliti lebih lanjut.

Aktivitas enzim pencernaan pada udang yang diberi pakan penambahan ekstrak sargassum diduga memiliki aktivitas yang lebih baik menyebabkan efektivitas pemanfaatan nutrisi pakan, kemudian dikonversikan ke dalam bentuk biomassa tubuh. Yone et al. (1986) mengungkapkan pertumbuhan yang terjadi ditandai dijelaskan oleh percepatan penyerapan nutrisi dari adanya kandungan bahan rumput laut. Hal ini didukung dengan nilai FCR yang rendah pada perlakuan penambahan ekstrak sargassum enzimatik protease dan karbohidrase, masing-masing

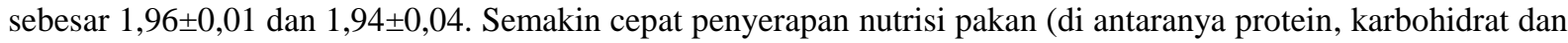
serat) menandakan semakin banyak nutrisi yang dapat dimanfaatkan untuk diubah menjadi sel-sel penyusun tubuh. Niu et al. (2015) mengungkapkan dalam penelitiannya, udang windu ( $P$. monodon) yang diberi pakan yang mengandung $3 \%$ U. pinnatifida memiliki komposisi penyusun tubuh berupa protein 70,18 (\% bahan kering) dan lemak 4,17 (\% bahan kering). Sementara udang windu (P. monodon) yang diberi pakan dengan kandungan $0 \% U$. pinnatifida memiliki komposisi penyusun tubuh protein dan lemak yang lebih rendah, masing-masing 68,61 dan 3,41 (\% bahan kering).

Penambahan ekstrak sargassum hasil ekstraksi enzimatik, baik ekstrak protease atau karbohidrase, juga berpengaruh nyata $(\mathrm{P}<0,05)$ terhadap FCR udang vaname (L. vannamei). Hasil penelitian ini menunjukkan bahwa telah terjadi efektifitas pemanfaatan nutrisi pada pakan yang mengandung ekstrak sargassum dibandingkan dengan pakan yang tidak mengandung ekstrak sargassum. Sudaryono et al. (2015a) mengungkapkan bahwa suplementasi S. cristaefolium $200-1000 \mathrm{mg} / \mathrm{kg}$ cukup dan efektif untuk meningkatkan pemanfaatan semua nutrisi yang ada dalam pakan. Lin et al. (2017) menguatkan bahwa udang L. vannamei yang diberi pakan dengan kandungan 0,252,5 g/kg ekstrak sargassum mampu memanfaatkan pakan lebih efisien. Cruz-Suarez et al. (2000) menyatakan bahwa juvenil udang vaname yang diberi pakan dengan tambahan polisakarida Macrocystis pyrifera menghasilkan peningkatan daya cerna nutrisi, pemanfaatan protein yang efisien, dan meningkatkan laju pertumbuhan.

Peran dari kandungan bahan aktif, senyawa polifenol-florotannin, pada pakan diduga menyebabkan proses penyerapan nutrisi oleh usus menjadi lebih baik yang dipengaruhi oleh enzim pencernaan. Corona et al. (2016) 
menerangkan bahwa di bagian atas gastrointestinal, polifenol berperan sebagai substrat sejumlah enzim dan memengaruhi metabolisme oleh enzim glukosidase, enzim fase I (hidrolisis dan oksidasi) dan enzim fase II (konjugasi dan detoksifikasi) yang ditemukan baik di usus kecil atau hati. Selain itu, mekanisme peningkatan daya cerna udang yang disuplementasi ekstrak sargassum telah dijelaskan oleh Schleder et al. (2018b), pengunaan rumput laut $S$. filipendula dan $U$. pinnatifida dalam pakan meningkatkan luas lapisan permukaan epitel usus udang dan memengaruhi penyerapan nutrisi. Hal ini diperkuat oleh Yu et al. (2016), bahwa penambahan 2\% biomassa G. lemaneiformis meningkatkan panjang mikrovili sel dari epitel usus penyerapan udang vaname.

\section{KESIMPULAN DAN SARAN Kesimpulan}

Penambahan ekstrak sargassum hasil ekstraksi enzimatik pada pakan berpengaruh nyata $(\mathrm{P}<0,05)$ terhadap performa pertumbuhan yaitu laju pertumbuhan spesifik (SGR) dan rasio konversi pakan (FCR) udang vaname ( $L$. Vannamei).

\section{Saran} karbohidrase.

Perlu dilakukan penelitian pada ekstrak rumput laut yang berbeda hasil ekstraksi enzimatik protease dan

\section{UCAPAN TERIMAKASIH}

Terima kasih kepada PDUPT (Penelitian Dasar Unggulan Perguruan Tinggi) yang telah memberikan bantuan dana dalam penelitian ini.

\section{DAFTAR PUSTAKA}

Arizo, M.A.M., E.C. Simeon, M.J.T. Layosa, R.M.M. Mortel, C.M.B. Pineda, J.J.E. Lim, dan M.B.B. Maningas. 2015. Crude Fucoidan from Sargassum polycystum Stimulates Growth and Immune Response of Macrobrachium rosenbergii Againts White Spot Syndrome Virus (WSSV). AACL Bioflux, 8(4):535-543.

Azad, I.S., A. Panigrahi, C. Gopal, S. Paulpandi, C. Mahima, dan P. Ravichandran. 2005. Routes of Immunostimulation vis-a -vis Survival and Growth of Penaeus monodon Postlarvae. Aquaculture, 248:227-234.

Boulila, A., I. Hassen, L. Haouari, F. Mejri, I.B. Amor, H. Casabianca dan K. Hosni. 2015. Enzyme-assisted Extraction of Bioactive Compound from Bay Leaves (Laurus nobilis L.). Industrial Crops and Products, 74:485-493.

Charoensiddhi, S., A.J. Lorbeer, J. Lahnstein, V. Bulone, C.M.M. Franco dan W. Zhang. 2016. Enzyme-assisted extraction of carbohydrates from the brown algaEcklonia radiata: Effect of enzyme type, $\mathrm{pH}$ and buffer on sugar yieldand molecular weight profiles. Process Biochemistry, 51:1503-1510.

Corona, G., Ji, Y., Anegboonlap, P., Hotchkiss, S., Gill, C., Yaqoob, P., Spencer, J.P.E., dan Rowland, I. 2016. Gastrointestinal Modifications and Bioavailability of Brown Seaweed Phlorotannins and Effects on Inflammatory Markers. British Journal of Nutrition, 115:1240-1253.

Cruz-Suarez, L.E., D. Ricque-Marie, M. Tapia-Salazar dan C. Guajardo-Barbosa. 2000. Uso de harina de kelp (Macrocystis pyrifera) en alimentos para camarón. In: Cruz -Suárez, L.E., Ricque-Marie, D., TapiaSalazar, M., Olvera-Novoa, M.A. y Civera-Cerecedo, R., (Eds.). Avances en Nutrición Acuícola V. Memorias del V Simposium Internacional de Nutrición Acuícola. 19-22 Noviembre, 2000. Mérida, Yucatán.

Denis, C., H.L. Jeune, P. Gaudin, J. Fleurence. 2009. An Evaluation of Methods for Quantifying the Enzymatic Degradation of Red Seaweed Grateloupia turuturu. J. Appl. Phycol., 21:153-159.

Ferreira, N.C., C. Bonetti dan W.Q. Seiffert. 2011. Hydrological and Water Quality Indices as Management Tools in Marine Shrimp Culture. Aquaculture, 318:425-433.

Giang, H.T., T.T. Giang, D.T.H. Oanh, T.S. Ngoc, dan V.N. Ut. 2016. Chemical Composition, Antioxidant Activity of Crude Polysaccharide Extracted from Brown Seaweed Sargassum Microcystum and its Effect on Growth Performance and Survival of Whiteleg Shrimp Litopenaeus Vannamei via Dietary Administration. Can Tho University Journal of Science, 4:71-80.

Hepher, B. 1988. Nutrition of Pond Fish. Cambridge University Press. Cambridge. 162p.

Kementerian Kelautan dan Perikanan Indonesia. 2018. Dashboard Produksi Perikanan dan Kelautan. Satu Data. https://satudata.kkp.go.id/dashboard_produksi.

Lin, Y-H., Y-C. Su, dan W. Cheng. 2017. Simple Heat Processing Of Brown Seaweed Sargassum cristaefolium Supplementation in Diet can Improve Growth, Immune Responses and Survival to Vibrio alginolyticus of White Shrimp, Litopenaeus vannamei. Journal of Marine Science and Technology, 25(2):242-248. 
Mohanty, R.K., S.K. Ambast, P. Panigrahi dan K.G. Mandal. 2018. Water Quality Suitability and Water Use Indices: Useful Management Tools in Coastal Aquaculture of Litopenaeus vannamei. Aquaculture, 485:210-219.

Niu, J., X. Chen, X. Lu, S-G. Jiang, H-Z. Lin, Y-J. Liu, Z. Huang, J. Wang, Y. Wang, dan L-X. Tian. 2015. Effects of Different Levels of Dietary Wakame (Undaria pinnatifida) on Growth, Immunity and Intestinal Structure of Juvenile Penaeus monodon. Aquaculture, 435:78-85.

Puspita, M., M. Deniel, I. Widiowati, O.K. Radjasa, P. Douzenel, C. Marty, L. Vandajon, G. Bodeux, dan N. Bourgougnon. 2017. Total Phenolic Content and Biological Activities of Enzymatic Extracts from Sargassum muticum (Yendo) Fensholt. J. Appl. Phycol., 29:2521-2537.

Ridlo, A. dan R. Pramesti. 2009. Aplikasi Ekstrak Rumput Laut sebagai Agen Imunostimulan Sistem Pertahanan Non Spesifik pada Udang (Litopennaeus vannamei). Ilmu Kelautan, 14(3):133-137.

Rohmin, M.F.T., G. Mahasri dan F.A. Rantam. 2017. Response Analysis of Urban Vaname (Litopenaeus vannamei) Which is Exposed to Crude Protein Zoothamniumpenaei Oral and Maintained in Ponds. $J$. Biosains Pascasarjana, 19(2).

Sahara, R. 2017. Efisiensi Pemanfaatan Pakan dan Pertumbuhan Benih Ikan Lele (Clarias sp.) dengan Penambahan Tepung Alga Coklat (Sargassum sp.) dalam Pakan. J. Sains dan Tekonologi Akuakultur, 1(1):38-46.

Schleder, D.D., J.R. de Rosa, A.M. Guimaraes, F. Ramlov, M. Maraschin, W.Q. Seiffert, F.d.N. Vierra, L. Hayashi dan E.R. Andreatta. 2017a. Brown Seaweeds as Feed Additive for White-leg Shrimp: Effects on Thermal Stress Resistance, Midgut Microbiology, and Immunology. J. Appl. Phycol., 29:2471-2477.

Schleder, D.D., L.G.B. Peruch, M.A. Poli, T.H. Ferreira, C.P. Silva, E.R. Andreatta, L. Hayashi dan F.d.N. Vierra. 2018b. Effect of Brown Seaweeds on Pacific White Shrimp Growth Performance, Gut Morphology, Digestive Enzymes Activity and Resistance to White Spot Virus. Aquaculture, 495:359-365.

Sivagnanavelmurugan, M., T. Marudhupandi, A. Palavesam, dan G. Immanuel. 2012. Antiviral Effect of Fucoidan Extracted from the Brown Seaweed, Sargassum wightii, on Shrimp Penaeus monodon Postlarvae against White Spot Syndrome Virus. J. of The World Aquaculture Society, 43(5):697-706.

Subagiyo. 2008. Uji Pemanfaatan Rumput Laut Halimeda sp. Sebagai Sumber Makanan Fungsional untuk Memodulasi Sistem Pertahanan Non Spesifik pada Udang Putih (Litopenaeus vannamei). Ilmu Kelautan, 14(3):142-149.

Sudaryono, A., A.H.C. Haditomo, dan A. Isnansetyo. 2015a. Evaluation of Dietry Supplementation of Aqueous Extract of Brown Algae Sargassum cristaefolium on Growth Performance and Feed Utilizaton of Juvenile White Shrimp Litopenaeus vannamei. AACL Bioflux, 8(2):142-149.

Sudaryono, A., D. Chilmawati, dan T. Susilowati. 2018b. Oral Administration of Hot-water Extract of Tropical Brown Seaweed, Sargassum cristaefolium, to Enhance Immune Response, Stress Tolerance, and Resistance of White Shrimp, Litopenaeus vannamei, to Vibrio parahaemolyticus. J. of World Aqua. Society, doi: 10.1111/jaws.12527.

Tacon, A.G. 1987. The Nutrition and Feeding of Farmed Fish and Shrimp - A Training Mannual. FAO of The United Nations. Brazil. 106-109p.

Wijesinghe, W.A.J.P. dan Y-J. Jeon. 2012. Enzyme-assistant Extraction (EAE) of Bioactive Components: a Useful Approach for Recovery of Industrially Important Metabolites from Seaweeds: A review. Fitoterapia, 83:6-12.

Yeh, S.T. dan J.C. Chen. 2008. Immunomodulation by Carrageenans in the White Shrimp Litopenaeus vannamei and its Resistance Against Vibrio alginolyticus. Aquaculture, 276:22-28.

Yone, Y., Furuichi, M., Urano, K., 1986. Effects of Dietary Wakame Undaria penatifida and Ascophyllum nodosum Supplements on Growth, Feed Efficiency, and Proximate Compositions of Liver and Muscle of Red Sea Bream. Bull. Jpn. Soc. Sci. Fish, 52:1465-1468.

Yu, Y-Y., W-D. Chen, Y-J. Liu, J. Niu, M. Chen, dan L-X. Tian. 2016. Effect of Different Dietary Levels of Gracilaria lemaneiformis Dry Power on Growth Performance, Hematological Parameters and Intestinal Structure of Juvenile Pacific White Shrimp (Litopenaeus vannamei). Aquaculture, 450:356-362.

Yudiati E., A. Isnansetyo, Murwantoko, Ayuningtyas, Triyanto dan C.R. Handayani. 2016. Innate ImmuneStimulating and Immune Genes Up-Regulating Activities of Three Types of Alginate from Sargassum siliquosum in Pacific White Shrimp, Litopenaeus vannamei. Fish \& Shellfish Immunology, 54:46-53. 